\title{
Review on Aquaculture Research in Cameroon: Fish Farming
}

\author{
Temegne $\mathrm{NC}^{1} *$ and Momo NJ² \\ ${ }^{1}$ Department of Plant Biology, Faculty of Science, University of Yaounde I, Cameroon \\ 2Department of Animal Biology, Faculty of Science, University of Yaounde I, \\ Cameroon
}

*Corresponding author: Temegne Nono Carine, Department of Plant Biology, Faculty of Science, University of Yaounde I, PO. Box 812 Yaounde, Cameroon, Tel: (+237) 651323 456; Email: nonocarine2003@gmail.com

\section{Review Article \\ Volume 3 Issue 3}

Received Date: July 30, 2019

Published Date: August 19, 2019

DOI: $10.23880 /$ ijoac- 16000170

\section{Abstract}

Aquaculture in the form of fish farming was introduced in Cameroon in 1948. But, it still remains marginal. The population's demand is estimated at more than 400,000 tones, but production is still insufficient to meet this demand. Indeed, the contribution of fisheries and aquaculture is less than $1 \%$ of GDP and those of aquaculture less than $0.1 \%$. However, aquaculture is the fastest growing food production sector in the world. Research being the basis and the backbone of development, this review is an inventory of works of aquaculture research in Cameroon. To the most popular species (common carp, North African catfish and tilapia) is added today a dozen of endemic species. The research has been concerned in recent years with fry production, nutrition, composition, domestication of fish and also their parasites. Important work have also been done on the intensification of fish farming, the use of agricultural by-products in aquaculture, the promotion of integrated aquaculture and on the potential negative impacts of fish farming on the prevalence of diseases and on the environment. It also placed particular emphasis on the constraints of fish farming in Cameroon, particularly on the difficulty of adoption of new farming innovations, the relative profitability of fish farming, the need for support to fish farmers, the relation research-farmer, the financing of fish farming, and many other constraints. This basic work already done by research can be improved. It will thus be able to contribute in reducing the large deficit of Cameroonian aquaculture production.

Keywords: Cameroon; Fingerlings; Fish Farming Research; Ponds; Production Constraints

\section{Introduction}

According to FAO, aquaculture in the form of fish farming was introduced in Cameroon in 1948 [1]. The aquaculture practiced is only in ponds and freshwater [2]. Fish farming was introduced in Cameroon as a component of the protein deficiency solution made more acute after the Second World War. The colonial administration therefore established demonstration ponds from 1948. Several government stations such as Bertoua (1948), Ebolowa (1948), Yaoundé (1948), Ngaoundéré, (1949), Bétaré Oya (1954), Foumban (1954), Ku-Bomé (1972), Bambui-Nkwen (1973), Bamessing (1973), Ngounougou (1987), Bangante... were thus set up for the distribution 


\section{International Journal of Oceanography \& Aquaculture}

of fry to fish farmers and training [3]. But, the contribution of fisheries and aquaculture is less than $1 \%$ of GDP and the share of aquaculture less than $0.1 \%$. Cameroon is experiencing a steady decline in national production of capture fisheries. Indeed, the Ministry of livestock fisheries and animal industries (MINEPIA) of Cameroon recently indicated that, as far as fish is concerned, imports remain significant $(181,678$ tones, worth FCFA 114.3 billion in 2017); but they have nevertheless experienced a decrease of $55 \%$ between 2016 and 2017, due to the increase in local production [4]. To fill the gap, it imports increasing amounts of frozen fish (Table 1) [5]. In order to sustainably feed the evergrowing population, it will be necessary to increase production and reduce imports. Research can contribute to the increase of fish production, the objective of this work is to take stock of aquaculture research in Cameroon.

\begin{tabular}{|c|c|c|c|}
\hline Products & $\mathbf{2 0 1 1}$ & $\mathbf{2 0 1 2}$ & $\mathbf{2 0 1 3}$ \\
\hline Mackarel & 98,881 & 86,146 & 53,251 \\
\hline Sardine/sardinella & 6,549 & 1,975 & 10,976 \\
\hline Tilapia & - & 0 & 3,834 \\
\hline Catfish & - & 0 & 670 \\
\hline Bars/captain & 14,051 & 6,627 & 11,876 \\
\hline Various fish & 71,540 & 64,665 & 35,991 \\
\hline Other hydrolysates & 2,339 & 1,171 & 529 \\
\hline Tuna & 126 & 0 & 7 \\
\hline Canned fish & 1,129 & 1,819 & 1,475 \\
\hline Total & 194,615 & 162,403 & 118,609 \\
\hline
\end{tabular}

Table 1: Evolution of fish imports in Cameroon between 2011 and 2013 according to the Ministry of Agriculture and Rural Development [5].

\section{Cultured Species}

\section{Cultured Species for Food}

Fish species (Figure 1) which largely contribute to domestic production are common carp, North African catfish and tilapia. There are several tilapia species in Cameroon, but the Nile tilapia (Oreochromis niloticus) is the most interesting species in fish farming [6,7]. They are sturdy fish that can endure extreme water temperatures and low levels of dissolved oxygen. Natural breeding occurs almost in all types of water [6].

North African catfishes belong to the order of siluriformes. They are endemic, teleost (bony) fishes characterized by scaleless body and the presence of mandibular whiskers, among others. Clarias gariepinus because of its high economic value [8,9] is the most widely used species in Cameroon.

The common carp (Cyprinus carpio) is a cyprinid, imported from Israel in 1969. It adapts well to the tropical climate of the western highlands area since it reproduces naturally in pond.

Others species like Labeobarbus batesii [10], Tilapia zillii [11], Stomatepia mongo [12], African bonytongue or Kanga (Heterotis niloticus), snakehead (Parachanna obscura), banded jewel fish (Hemichromis fasciatus), gougeon (Barbus spp.) [13], Tilapia cameronensis [14] and Heterobranchus longifilis, are also breed. Stomatepia mongo also called the "Mongo" is a species of cichlid endemic to Lake Barombi Mbo in western Cameroon.

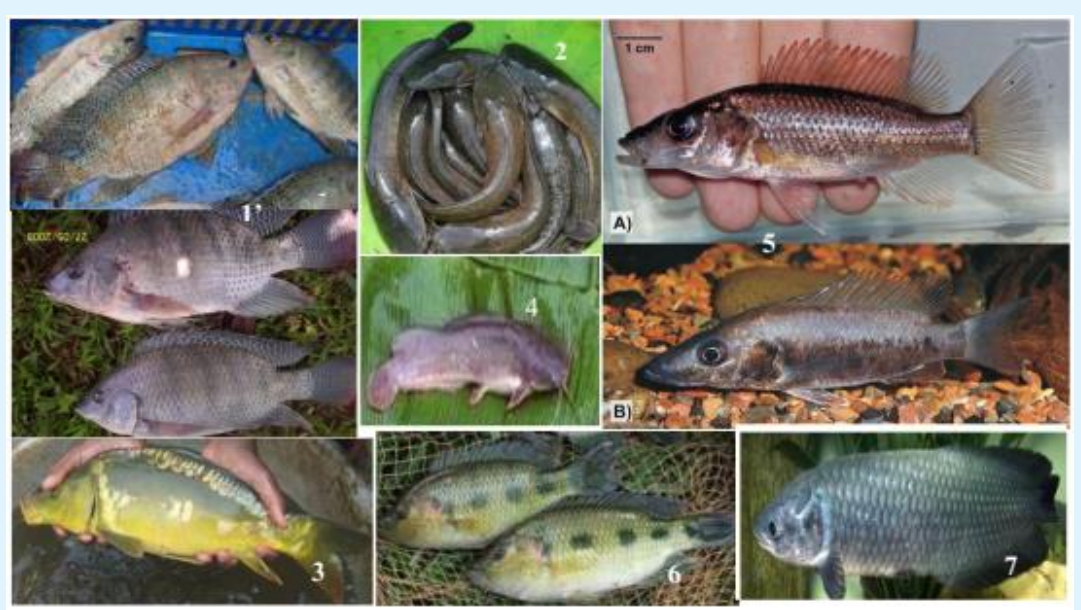

Figure 1: Some cultured fish species in Cameroon. 1: Oreochromis niloticus, 2: Clarias gariepinus, 3: Cyprinus carpio, 4: Heterobranchus sp, 5: Stomatepia mongo (A: freshly caught male, B: adult male), 6: Hemichromis fasciatus, 7: Heterotis niloticus $[11,13]$. 


\section{International Journal of Oceanography \& Aquaculture}

\section{Ornamental Aquarium Fish}

Several species of fish like Synodontis obesus broodfish [15], catfish [16] are domesticated and bred for exportation.

\section{Hybridization}

Some hybridization work has been carried out in Cameroon, particularly interspecies hybrids produced by artificial insemination of the African catfish, pure Clarias gariepinus females $\mathrm{X}$ pure $C$. anguillaris males in the Mount Cameroon Region [8]. These hybrid fingerlings of two mature female pure C. gariepinus (1 kg/fish) and one mature male $C$. anguillaris (1 kg/fish) was $10,471 \pm 126$ fingerlings with a high survival rate of $85.5 \%$.

\section{Composition, Nutrition and Fish Domestication}

Momentcham, et al. [17] determined the total amino acids and proximate composition of eggs, larvae, juveniles, immature and adults of Heterotis. The amino acid composition of eggs was very different from that of whole body tissues with lower levels of methionine, proline and glycine, and higher levels of arginine, histidine, isoleucine, leucine, threonine, valine, serine and alanine. The A/E ratios of adult Heterotis muscle tissue, IAA requirement profiles for Heterotis (larva to adult) were similar to those for other omnivorous fish species, with the exception of histidine and tryptophan [17].

Works on fish feeding is increasingly focused on food optimization, especially on species common to fish farming, to ensure a good yield [14,18-22]. The study has shown the importance of the partial replacement of fish meal by Moringa leaf powder [23] on the profit margin related to the feeding of Oreochromis niloticus fish, without however causing harm to the growth of fish. This study demonstrates the importance of valuing local byproducts.

The works were also carried out on the domestication and breeding of many species like ornamental aquarium fish (Synodontis obesus broodfish) for export [15]; Labeobarbus batesii $[10,24]$, catfish collected from the wild in polyculture with mixed sex tilapias [25] for food. In order to increase the production and productivity of juvenile fish in a pond, a study was carried out to evaluate the age of transfer of juvenile Clarias gariepinus to a pond [26]. From this work it emerges that the adequate age of fish transfer would be within 4-7 days range. Moreover, [27] has shown the importance of water renewal in the growth of these fish as part of optimal conditions for their growth without forgetting to take into account temperature, $\mathrm{pH}$, and ammonium.

\section{Socio-Economic Influence}

In Cameroon, fish farming creates direct jobs, it also improves income and the availability of food for households $[9,28]$. The socio-economy affects the type of fish farming used and the adoption of new fish farming technologies. The local group is a requisite condition to develop any farming innovation. The fish innovation is not an exception [29]. Wandji DN [30] indicated that the strong commercial orientation, the positive perception of profitability, the frequent contacts with the extension, the level of education are the main determinants of the adoption of fish farming in the Western Highlands of Cameroon. Little administrative presence and low effective local fish demand have a negative effect on the adoption process [31]. Indeed, in the Western region, 10 farms out of 13 have unregulated systems [32]. The demand and market access are low in rural areas compared to periurban and urban areas. So, the productivity, intensity and profitability grew more significantly in peri-urban areas with good market access, in comparison to rural areas [33]. Indeed, the development of extensive systems (large-scale and lowinput) in rural parts of Centre Region of Cameroon is principally lead by vast available lands. For semiintensive systems in both regions (small-scale (Figure 2) and high-input in the Western Region, large-scale and high-input in periurban areas of the Centre Region), horizontal integration is not sufficient to make fish production profitable and sustainable [34]. More intensive fish farms tend towards vertical integration, in which farmers establish close links with input suppliers.

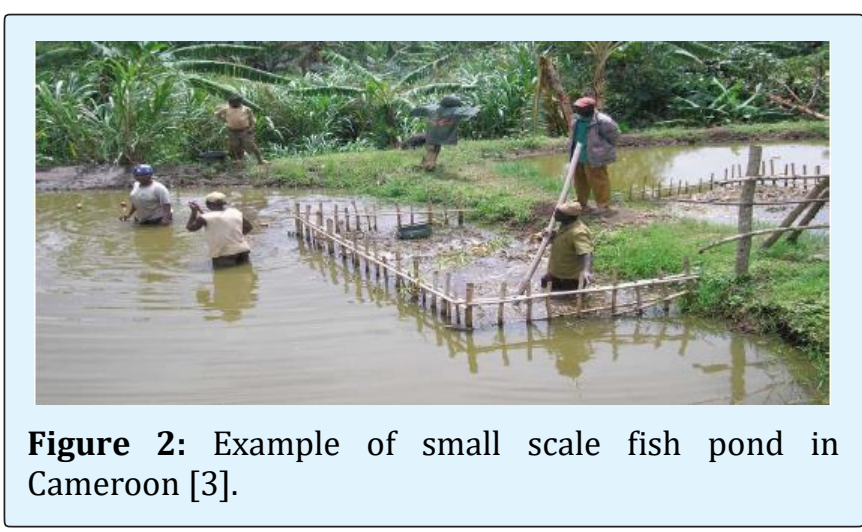

Main causes of low output of fish farming are: lack of knowledge of fish farming principles by farmers, 


\section{International Journal of Oceanography \& Aquaculture}

trialability, relative advantage, complexity of the innovation, lack and poor quality of fingerlings and feeds, and lack of technical improvement by extension agents and researchers which need to consider the local complexity of farming systems to develop and intensify fish production $[3,31,34]$. The low production of fish farming can also be explained by the fact that the majority of fish farmers (79\%) are men. Indeed, very few women (21\%) perform this activity in the Centre, Coastal and West regions of Cameroon [9]. The disinterestedness of young people can also explain this low production in fish farming. Indeed, in Cameroon, the majority of young people are not involved in fish farming, leaving the task to the older generation who tends to practice agriculture traditionally despite technological progress [9].

Oben BO, et al. [35] showed a positive and direct relationship between the profitability of small integrated fish-rice-poultry farms with agricultural incomes for socio-economic parameters such as plot size, labor, credit, education, land tenure, access to extension and enterprise integration. Investment is a key factor in aquaculture production. Indeed, Brummett RE, et al. [36] showed that on five semi-intensive fish farms in Yaounde, two farmers lose money each year, only two farms can be considered as solid investments and finally the recovery period for the initial investment on the farms. Farms turning a profit range from five to 28 years.

According to Brummett RE, et al. [37], the transfer of the researcher's knowledge to the farmer is necessary for the success of integrated aquaculture in Cameroon. The adaptation of development plan to socio-economic and environmental contexts is a requirement to hope for an expansion in fish pond aquaculture production in Africa in general and in Cameroon in particular [34]. Integration technology based on the use of agricultural by-products as feedstock inputs is also driving intensification. It increased by three times the fish production, and by 5 times the net returns over pre-project levels [33]. In addition, the organization of new training courses on fisheries statistics in Cameroon is a definite contribution to the development of this sector of activity [38].

\section{Health and Environment Influences}

Intensive freshwater fish farming is associated with the fertilization of ponds with animal droppings and a high stocking density compared to normal. These directly expose fish to a range of factors pre-disposing to bacterial infections; and indirectly the human if the freshwater farm products contain human pathogenic bacteria. Research in Cameroon has focused on one hand on the identification of fish parasites and on the other hand on the search for solutions to eradicate these parasites. The work of 39. Kemajou TAL, et al. [39] have shown that fish are potential reservoirs of food poisoning microorganisms. Their work demonstrated that E. coli was most abundant in the intestines and then in gills. It was followed by Enterobacter cloacae which was also abundant in the intestines and gills. Other bacteria identified were Salmonella sp, Citrobacter freundii, Acinetobacter baumannii, Vibrio fluvialis, Plesiomonas shigelloides, Raoultella ornithinolytica, Erwinia sp, Pasteurella pneumotropica and Pseudomonas sp [39]. In addition, Nchoutpouen E, et al. [40] studied Myxosporidium parasites of Oreochromis niloticus from the Noun River in Kouoptamo and the ponds of Foumban in western Cameroon. They found ten species of parasites. Myxosporean spores were most prevalent in the kidney and spleen, but no host preference was found. A seasonal effect was observed in Foumban with a high infection rate for Myxobolus tilapiae, M. camerounensis and M. israelensis during the rainy season, whereas in the Noun River there was no effect significant seasonal [40]. Several other works have been carried out in Cameroon on the systematics of water fish parasites [41-45]. In order to increase and ensure quality and quantity of fish production in Cameroon, Kaktcham PM, et al. [46] made a review on a potential of lactic acid bacteria to be used as diseases controlling agents.

In addition to the contamination of humans by E. coli via the consumption of parasitized fish; mismanagement of fish activity may also create favorable environmental conditions for the development of vectors of other diseases, such as female Anopheles. Indeed, Kramek N [47] has defined the criteria for determining how the prevalence of malaria in arable land areas may change with planned irrigation and fish farming projects.

Fish farms would also contribute to air pollution. Indeed, operations in ponds induce gas emissions, such as carbon dioxide $\left(\mathrm{CO}_{2}\right)$, oxygen $\left(\mathrm{O}_{2}\right)$, ammonia $\left(\mathrm{NH}_{3}\right)$, methane $\left(\mathrm{CH}_{4}\right)$, nitrous oxide $\left(\mathrm{N}_{2} \mathrm{O}\right)$ and nitrogen $\left(\mathrm{N}_{2}\right)$. Efole ET, et al. [48] estimated the effect of pond management practices on ammonia and greenhouse gas emissions. They found that $\mathrm{CO}_{2}$ gradients are related to fish densities in ponds and organic inputs. $\mathrm{CH}_{4}$ emissions in ponds were related to higher oxygen rates in the water due to higher photosynthesis and a large deposit of dead plankton on the bottom.

Fish farming is also a source of pollution via the eutrophication of water. Indeed, Efole ET, et al. [49] have shown that, compared to other aquaculture systems in the 


\section{International Journal of Oceanography \& Aquaculture}

literature, the impact of eutrophication is higher for Cameroonian farms, which are integrated fish farming with other agricultural production, and in which fish ponds were fertilized by pig manure and / or crop byproducts. This eutrophication is mainly due to the use of pig manure and wheat bran for the supply of nutrients. The management of water and nutrients in fish farming systems in Cameroon will need to be improved not only to increase the efficiency of these fish farms but also to make them environmentally friendly.

\section{Analysis}

Several fish species are currently bred in Cameroon for human consumption. Some work has indeed been done in Cameroon on the domestication of fish. But, research should focus more work on the domestication of endemic wild species and on the adaptation of highyielding introduced species. In addition, breeding ornamental fish species for the aquarium could be a viable future economic outcome for the development of aquaculture in Cameroon. The fry is a key tool in aquaculture production, research should further work on seed availability in quantity and quality for the fish production areas of the countries. These fish are an important source of protein and amino acids for humans. The study of the nutritional composition of fish is therefore important for dietary and dietary reasons. Factors (nutrition, types of food, by-products of agriculture, inputs, etc.) influencing their production and composition must therefore be controlled. In Cameroon, as in other countries, the socio-economy affects fish farming through the choice of the type of fish farm used, the adoption of fish farming, the adoption of new fish farming technologies, the financing of aquaculture farms etc. Indeed, this sector of activity faces many constraints (lack of knowledge of fish farming principles by farmers, trialability, relative advantage, complexity of the innovation, lack and poor quality of fingerlings and feeds, and lack of technical improvement by extension agents and researchers) and challenges in Cameroon. Although aquaculture in general and fish farming in particular is a promising sector in Cameroon, research should focus on quality control of production. Some studies have indeed highlighted potential risks of contamination of humans by fish containing E. coli. The environment is not at rest because aquaculture can be a source of pollution via the release of greenhouse gases into the environment and the eutrophication of rivers by their waste. It could also promote the development of female Anopheles and contribute to the increase of malaria incidence in the production areas. The expansion of fish farming in Cameroon needs to go through the development of aquaculture research. And it should take into account all the factors influencing its development for sustainable production.

\section{Conclusion}

Some studies were conducted in Cameroon on fish farming, but it remains marginal. Despite the impressive number of development projects and programs that have taken place over the years, aquaculture has so far not been successfully integrated into the rural economy like other traditional cattle, small ruminants or poultry. Inputs provided by public or non-governmental organizations, favorable environmental conditions and socio-cultural attitudes act together as determinants factor of fish farming adoption.

\section{References}

1. FAO (2005) National Aquaculture Sector Overview: Cameroon. FAO, Rome, Italy, pp: 1-9.

2. Satia NBP (1991) History and general overview. In: National Aquaculture Sector Overview: Cameroon. FAO (2005), Rome, Italy.

3. Pouomogne V, Pemsl D (2008) Recommendation domains for pons aquaculture, country case study. Development and status of freshwater aquaculture in Cameroon. World Fish Center, Studies and Reviews No. 1871, Penang, Malaysia, pp: 60.

4. Anonymous (2019) Cameroon plans large-scale aquaculture to reduce fish imports. Business in Cameroon.

5. INS (2015) Pêche et élevage, chapitre 15. In: Annuaire statistique du Cameroun (INS), (Ed.), Yaounde, Cameroon, pp: 257-268.

6. Assiah VF (1996) La pisciculture en eau douce à petite échelle. Agrodok/Agromisa $6 \quad 700$ AA/ ACP/CEE/CTA, Wageningen, pp: 81.

7. Pouomogne V, Brummett RE, Gatchouko M (2010) Impacts of aquaculture development projects in Western Cameroon. J Appl Aquaculture 22(2): 93108.

8. Oben PM, Oben BO, Akoachere R, Joseph E (2015) Induced spawning, survival and growth of an African catfish hybrid (female Clarias gariepinus and male Clarias anguillaris) fingerlings relative to their 


\section{International Journal of Oceanography \& Aquaculture}

parental species in the mount Cameroon region. Trop Freshwat Biol, pp: 24.

9. Mang'unyi E, Ngota BL (2018) Linkage between small-scale aquaculture and rural households socioeconomic effects: a Cameroonian case study. Int J Agri Educ Ext 4(1): 140-150.

10. Tiogue TC, Nguenga D, Tekwombuo J, Tekou G (2015) Intestine morphometrics and feeding habits of the African Carp Labeobarbus batesii (Pisces: Cyprinidae) from the Mbô floodplain rivers. J Biol Nat 3(1): 1-9.

11. Mougang FJ, Zanga AD (2015) Pisciculture au Cameroun. EICA (Egyptian International Centre for Agriculture), Yaounde, Cameroun, pp: 26.

12. Musilová Z, Indermaur A, Nyom ARB, Tropek R, Martin C, et al. (2014) Persistence of Stomatepia mongo, an Endemic Cichlid Fish of the Barombi Mbo Crater Lake, Southwestern Cameroon, with Notes on Its Life History and Behavior. Copeia 14(3): 556-560.

13. Bigwa C (2013) Feasibility of aquaculture in Cameroon: the case of the Noun Division in the West Region. UNU, Tokyo, Japan, pp: 56.

14. Breine JJ, Nguenga D, Teugels GG, Ollevier F (1996) A comparative study on the effect of stocking density and feeding regime on the growth rate of Tilapia cameronensis and Oreochromis niloticus (Cichlidae) in fish culture in Cameroon. Aquat Living Resour 9(1): 51-56.

15. Oben PM, Oben BO (2003) Preliminary study on the domestication of broodstock of an ornamental aquarium fish, Synodontis obesus (Teleostei: Mochokidae) in concrete tanks. Trop Freshwat Biol 12/13: 137-153.

16. Njieassam ES (2016) Evaluating Water Quality Parameters for Tank Aquaculture of Cat Fish in Cameroon. J Ecosys Ecograph 6: 203.

17. Momentcham SE, Whatelet B, Pouomogne V, Kestemont P (2010) Egg and whole-body amino acid profile of African bonytongue (Heterotis niloticus) with an estimation of their dietary indispensable amino acids requirements. Fish Physiol Biochem 36(3): 531-538.

18. Breine JJ, Teugels GG, Podoor N, Ollevier F (1996) First data on rabbit dung as a water fertilizer in tropical fish culture and its effect on the growth of
Oreochromis niloticus (Pisces; Cichlidae). Hydrobiologia 321(2): 101-107.

19. Middendorp AJ (1995) Pond farming of Nile tilapia, Oreochromis niloticus (L.), in northern Cameroon. Feeding combinations of cottonseed cake and brewery waste in fingerling culture, hand-sexed male monosex culture, and mixed culture with police-fish, Clarias gariepinus (Burchell). Aquacult Res 26(10): 715-722.

20. Middendorp AJ (1995) Pond farming of Nile tilapia, Oreochromis niloticus (L.), in northern Cameroon. Adding hand-sexed male tilapia to graze the dense algal blooms in ponds with African catfish, Clarias gariepinus (Burchell). Aquacul Res 26(10): 749-754.

21. Middendorp AJ (1995) Pond farming of Nile tilapia, Oreochromis niloticus (L.), in northern Cameroon. Mixed culture of large tilapia ( $>200 \mathrm{~g}$ ) with cattle manure and cottonseed cake as pond inputs, and African catfish, Clarias gariepinus (Burchell), as police-fish. Aquacult Res 26(10): 723-730.

22. Efole ET (2011) Optimisation biotechnique de la pisciculture en étang dans le cadre du développement durable des Exploitations Familiales Agricoles au Cameroun. Thèse de Doctorat $\mathrm{PhD}$, Université Européenne de Bretagne, pp: 224.

23. Akamba Y, Yong SS, Angoni DE (2016) Effet de la substitution de la farine de poisson par la poudre des feuilles de Moringa oleifera sur les caractéristiques zootechniques et économiques du tilapia du nil (Oreochromis niloticus). BAHPA, pp: 51-59.

24. Tiogue TC, Tomedi MTE, Nguenga D, Tchoumboue J (2010) Caractéristiques de morphologie générale et de croissance du Cyprinidae africain Labeobarbus batesii dans la plaine inondable des Mbô, Cameroun. Int J Biol Chem Sci 4(6): 1988-2000.

25. Sadeu CB, Mikolasek O, Pouomogne V, Eyango MT (2013) The use of wild catfish (Clarias spp.) in combination with Nile Tilapia (Oreochromis niloticus L.) in Western Cameroon: Technical performances, interests, and limitations. J Appl Aquaculture 25(4): 359-368.

26. Kouam SJ (2017) Croissance et la survie des alevins de Clarias gariepinus en étang. EUE, pp: 72.

27. Nkengayi AE (2015) The effects of water exchange and water quality on growth and survival of Clarias 


\section{International Journal of Oceanography \& Aquaculture}

gariepinus (Fingerlings) along the Mount Cameroon Region.

28. Nyatchouba NBT, Kindong R, Xu L (2018) Reconstruction of historical fisheries profile of Cameroon. Int J Fisheries Sci Res 2(2): 1008.

29. Grosse 0, Oswald M (2010) The role of the farmers' group in fish innovation in an extension project's frame. Proceedings of the Innovation and Sustainable Development in Agriculture and food, Montpellier, ISDA, pp: 1-12.

30. Wandji DN, Pouomogne V, Nyemeck Binam J, Yossa Nouaga R (2012) Farmer's Perception and Adoption of New Aquaculture Technologies in the Western Highlands of Cameroon. Tropicultura 30(3): 180-184.

31. Ndah HT, Knierim A, Ndambi OA (2011) Fish Pond Aquaculture in Cameroon: A Field Survey of Determinants for Farmers' Adoption Behaviour. JAEE 17(4): 309-323.

32. Lazard J, Baruthio A, Mathé S, Rey-Valette H, Chia E (2010) Aquaculture system diversity and sustainable development: fish farms and their representation. Aquat Living Resour 23(2): 187-198.

33. Brummett RE, Gockowski J, Pouomogne V, Muir J (2011) Targeting agricultural research and extension for food security and poverty alleviation: A case study of fish farming in Central Cameroon. Food Policy 36(6): 805-814.

34. Efole TE, Mikolasek O, Aubin J, Eyango MT, Pouomogne V, et al. (2017) Sustainability of fish pond culture in rural farming systems of Central and Western Cameroon. Int J Agr Sustain 15(2): 1-15.

35. Oben BO, Molua EL, Oben PM (2015) Profitability of Small-Scale Integrated Fish-Rice-Poultry Farms in Cameroon. J Agric Sci 7(11): 232-244.

36. Brummett RE, Gockowski J, Bakwowi J, Etaba AD (2004) Analysis of aquaculture investments in periurban Yaoundé, Cameroon. Aquacult Econ Manage 8(5-6): 319-328.

37. Brummett RE, Jamu DM (2011) From researcher to farmer: partnerships in integrated aquaculture agriculture systems in Malawi and Cameroon. Int J Agr Sustain 9(1): 282-289.
38. FAO (2018) The State of World Fisheries and Aquaculture 2018-Meeting the sustainable development goals. FAO, Rome, pp: 227.

39. Kemajou TAL, Nchanji GT, Mbiatong TN, Akwanwi CM, Ebenye YB, et al. (2017) Characterisation of the bacteria microbiota of the Nile Tilapia (Oreochromis niloticus) from earth aquaculture farms.

40. Nchoutpouen E, Lekeufack FGB, Fomena A (2011) Structure and population dynamics of myxobolus infections in wild and cultured Oreochromis niloticus Linnaeus, 1758 in the Noun division (WestCameroon). J Cell Anim Biol 5(12): 254-264.

41. Fomena A, Bouix G (2000) Henneguya mbakaouensis sp. nov. Myxobolus nounensis sp. nov. And M. hydrocyni Kostoingué \& Toguebaye, 1994, Myxosporea (Myxozoa) parasites of Centropomidae, Cichlidae and Characidae (Teleosts) of the Sanaga basin in Cameroon (Central Africa). Parasite 7: 209214.

42. Fomena A, Lekeufack Folefack GB, Bouix G (2008) Three new species of Henneguya (Myxozoa: Myxosporea), parasites of fresh water fishes in Cameroon (Central Africa). J Afr Zool 4: 93-103.

43. Fomena A, Lekeufack Folefack GB, Bouix G (2010) Two new species of Myxidium (Myxosporea: Myxidiidae) parasites of fresh water fish in Cameroon. Parasite 17(1): 9-16.

44. Lekeufack FGB (2010) Faunistique et biologie des Myxosporidies (Myxozoa: Myxosporea) parasites de quelques Téléostéens dans la rivière Sangé (sous affluent du Wouri) au Cameroun. Thèse de Doctorat PhD. Université de Yaoundé I, pp: 181.

45. Lekeufack FGB, Defoueng Nza AS, Fomena A (2017) Three New Species of Myxobolus (Myxosporea: Myxobolidae), Parasites of Barbus callipterus Boulenger, 1907 in Cameroon. Asian J Biological Sci 10(3): 110-120.

46. Kaktcham PM, Zambou NF, Fonteh AF, Del Perez-Chabela M (2015) Aquaculture in Cameroon and potential of lactic acid bacteria to be used as diseases controlling agents: A Review. Nacameh 9(1): 1-18.

47. Kramek N (2009) Potential impacts of agricultural irrigation and fish farming on malaria prevalence; does the paddies paradox apply in Bome-Ngyenmbo, 


\section{International Journal of Oceanography \& Aquaculture}

Cameroon? 137th APHA Annual Meeting and Exposition.

48. Efole ET, Hassouna M, Robin P, Mikolasek O, Aubin J, et al. (2013) Estimation test of gaseous emissions from fishponds with contrasted inputs. Emissions of gas and dust from livestock. IFIP, pp: 35-39.
49. Efole ET, Aubin J, Mikolasek O, Corson MS, Tomedi ETM, et al. (2012) Environmental impacts of farms integrating aquaculture and agriculture in Cameroon. J Clean Prod 28: 208-214. 